\title{
Artikkeli
}

\section{Suomalaisen journalistin itseymmärrys muutosten keskellä}

Suomalainen journalismi on viime vuosina elänyt kiihtyvässä murroksessa. Tässä artikkelissa tarkastellaan, miten toimittajat itse kokevat muutoksen ja sen vaikutukset työhönsä ja omaan ammatilliseen itseymmärrykseensä. Artikkelin teoreettisena viitekehyksenä toimii professionalismin diskursiivinen rakentuminen ja fokuksessa on erityisesti se, millaiseen rooliin journalismiprofession ydinarvot - julkinen palvelu, autonomisuus, eettisyys, objektiivisuus ja ajankohtaisuus - asettuvat suomalaistoimittajien omissa tulkinnoissa. Artikkelin tulokset perustuvat määrällisen kyselytutkimuksen ja laadullisten ryhmähaastatteluiden analysointiin. Tulokset osoittavat, että toimittajat kokevat taloudellis-teknologiset muutokset ja niistä johtuvat resurssivähennykset kaikkein suurimmiksi muutoksiksi työssään. Myös yleisöyhteistyön rooli on korostunut. Näiden muutosten keskellä suomalaistoimittajien itseymmärrystä ohjaavat kuitenkin edelleen hyvin vahvasti professionalismin ydinarvot autonomisuudesta, objektiivisuudesta ja julkisesta palvelusta. Näiden pysyvyyttä selittää ainakin se, että niillä sekä motivoidaan omaa työntekoa että legitimoidaan journalismin asemaa suhteessa ympäröivään yhteiskuntaan ja muuttuvaan mediakenttään. Tulosten perusteella ajankohtaisuuden ideaali on muutoksen keskellä entisestään vahvistunut, kun taas eettisyyteen liittyvät ammatilliset arvot ovat selkein esimerkki ideaalin ja käytännön välisestä ristiriidasta: arvona eettisyyteen halutaan sitoutua tiukasti, mutta toiminnan tasolla siitä joudutaan käymään jatkuvaa neuvottelua.

AVAINSANAT: ammatillisuus, journalismi, professio, toimittajat, ydinarvot

$\mathrm{V}$ imeisten vuosikymmenten aikana journalismi on elänyt suuressa murroksessa. Teknologinen kehitys ja sääntelyn purku ovat kiihdyttäneet journalismin tarjonnan sekä mediakilpailun lisääntymistä maailmalla jo 1970-luvun lopulta saakka (Conboy 2004, 205), ja 2000-luvulla muutosvauhti on vain kasvanut Internetin myötä. Muutosten seurauksena journalismin asema on monella tapaa horjunut. Journalistit jou- 
tuvat mediakilpailussa pärjätäkseen ottamaan yhä useammin huomioon yleisöjen vaikeasti ymmärrettäviä mielihaluja ja kilpailemaan myös ei-journalistisen sisällöntuotannon kanssa - vieläpä aiempaa useammilla julkaisualustoilla. Journalismi, joka on länsimaissa pitkään ollut institutionalisoitunut, vakiintuneen ammattikunnan ylläpitämä suhteellisen selvärajainen toimija, on nykyisessä viestintäympäristössä vain yksi viestinnällinen toimija monien muiden joukossa (ks. esim. Heinonen \& Luostarinen 2008).

Myös toimittajien työtilanne on entistä epävakaampi: esimerkiksi muutoksen eturintamassa Yhdysvalloissa sanomalehtijournalistien määrä on vähentynyt 200o-luvulla noin 30 \% (Edmonds ym. 2013), ja erilaiset epätyypilliset työsuhteet ovat yleistymässä. Suomessakin viime vuodet ovat olleet murrosaikaa, kun yt-neuvotteluista, ulkoistamisista ja uusista työjärjestelyistä on tullut toimituksissa arkipäivää (Honkonen \& Lankinen 2012, 23-27). Muutosten seurauksena Journalistiliiton jäsenmäärä kääntyi vuonna 2012 pitkän nousukauden jälkeen laskuun, joka on sittemmin jatkunut (SJL 2014). Muuttuvassa ympäristössä journalismia työkseen tekevät ammattilaiset joutuvat jatkuvasti (uudelleen)määrittelemään - ja jopa puolustamaan - omaa työtään sekä sen rajoja.

Tämän artikkelin kohteena on suomalaisten journalistien ammatillinen itseymmärrys näissä muuttuvissa olosuhteissa, 2010-luvulla. Artikkelin tutkimuskysymys on: Mitkä asiat ovat toimittajien omien näkemysten mukaan muuttaneet journalismia ja mitä vaikutuksia näillä muutoksilla on heidän työhönsä ja journalismiprofession ydinarvoihin? Artikkeli luo näkökulman siihen, kuinka toimittajat selittävät käsityksiään journalistin tehtävistä ja rooleista muuttuvassa nykytilanteessa ja samalla rakentavat journalismin professionaalisuutta diskursiivisesti. Esittelemme aluksi tutkimuksen teoreettisen viitekehyksen sekä aineistot ja menetelmät. Paneudumme sitten empiirisesti journalistien kokemiin muutoksiin. Tämän jälkeen perehdymme toimittajien itseymmärryksessä muutostenkin keskellä pintansa pitäviin arvoihin. Lopuksi otamme lähempään tarkasteluun journalistien käsitykset eettisyydestä, sillä tämän arvon ympärillä käytävä neuvottelu tuo esille toimintaympäristön muutosten ja arvoytimen pysyvyyden välisen ristiriidan.

\section{Professionalismi ammattikuntaa koossapitävänä voimana}

Muuttuvassa mediaympäristössä voimme vielä melko vaivattomasti tunnistaa journalismin journalismiksi, kun sitä kohtaamme. Samoin tunnistamme toimittajien ammattikunnan. Sen tunnistettavuutta edesauttaa ja ylläpitää ajatus professionalismista: journalismi on julkisesti hyväksytty, erityistietoon ja -taitoon sekä koulutukseen perustuva toimiala, joka edesauttaa yhteiskunnan toimivuutta, jopa yhteistä hyvää (Pietilä 2012; vrt. Koljonen 2013a, 92-93).

Koska journalismin harjoittamiseen ei vaadita yksilökohtaista toimilupaa tai tutkintoa (vrt. lääkärit tai juristit), journalismi ei kuitenkaan ole klassinen säännelty professio. Sen sijaan on hyödyllistä tarkastella journalistista professionalismia konstruktivistisesta näkökulmasta, eli tutkia sitä, kuinka professionalismi rakentuu. Yhtäältä journalismin ammatillisuuden rakentumista määrittävät rakenteelliset seikat: ammattikunnan järjes- 
täytyminen, vakiintunut itsesääntely ja siihen liittyvät lait sekä oppilaitoksissa annettava journalistikoulutus ja niissä tehtävä tutkimus (ks. Koljonen 2013a, luku 4). Nämä institutionalisoituneet puitteet omalta osaltaan määrittävät, millaista journalismia esimerkiksi Suomessa harjoitetaan ja millaista on suomalaisjournalistien ammatillisuus.

Toisaalta journalismin ammatillisuus määrittyy diskursiivisissa käytännöissä: toiminnassa ja puheessa (Aldridge \& Evetts 2003, 554-557). Tämä tarkoittaa sitä, että journalistien omalla toiminnalla, esimerkiksi arkisella työllä ja sen arvioinnilla tai toisaalta vaikkapa juhlapuheilla ja linjapapereilla (Lehto 2006,10 ), on vaikutusta siihen, millaisena toimialana ja ammattina journalismi näyttäytyy ja millaiseksi se muokkaantuu. Diskursiivinen ymmärrys professiosta korostaa sitä, ettei ammatillisuudessa ole kyse vain rakenteista tai pysyvyydestä, vaan myös toiminnasta, jatkuvasta määrittelykamppailusta ja muutoksesta (Carpentier 2005).

Ei ole kuitenkaan suoraviivaisesti niin, että yksin rakenteellisuus tuottaisi pysyvyyden ja diskursiivisuus muutoksen, vaan kyse on dynamiikasta. Diskursiivisissa käytännöissäkin on paljon sellaista, mikä luo ammatillisuuteen pysyvyyttä, esimerkiksi journalistien tapa ymmärtää ammattinsa perusperiaatteet. Useiden tutkimusten mukaan journalistien itseymmärrys on nimittäin varsin hitaasti muuttuvaa (Lewis 2012; Ahva 2010). Etenkin tietyt arvot näyttävät muodostavan suhteellisen pysyvän ytimen, jonka ympärille journalistien ammatillinen omakuva ja ymmärrys työnsä tavoitteista rakentuu. Tässä artikkelissa olemme kiinnostuneita siitä, miten toimittajat itse ymmärtävät tämän arvoytimen.

Journalistisen ammatillisuuden ydinainesta on tutkittu ja määritelty paljon (ks. esim. Deuze 2005; Carpentier 2005; Hanitzsch 2007; Ahva 2010; Koljonen 2013a). Aikaisemman tutkimuksen mukaan voidaankin haarukoida arvoja tai normeja, joiden ympärille journalistinen itseymmärrys rakentuu. Tukeudumme tässä pääosin Deuzen (2005) esittämään ajatukseen, jonka mukaan journalismin ammatillisuus toimii ideologian tavoin: toimittajat ymmärtävät ja tekevät työnsä tiettyjen arvojen ohjaamina. Nämä arvot tuottavat journalistien itseymmärrykseen yhtenäisyyttä, vaikka niitä toki sovelletaan käytännössä eri tavoin eri konteksteissa (Deuze 2005, 445). Deuzen mukaan keskeisimmät arvot länsimaisessa journalismissa ovat: (1) julkinen palvelu, (2) autonomisuus, (3) eettisyys, (4) objektiivisuus ja (5) ajankohtaisuus. Monet näistä arvoista ovat yhteisiä muiden professioiden kanssa. Esimerkiksi julkisen palvelun, autonomisuuden ja eettisyyden ideaalit ovat professionalismiajattelussa yleisiä laajemminkin (ks. esim. Helander $(1993,40)$ teoksessa Pietilä 2012, 68), kun taas objektiivisuus ja ajankohtaisuus näyttäytyvät eritoten journalismin kannalta olennaisilta arvoilta.

Julkisen palvelun normi viittaa journalismille asetettuun tavoitteeseen osallistua julkisuuden tuottamiseen ja palvella näin yleisöä välittämällä sille tietoa ja avaamalla sille mahdollisuuden osallistua julkiseen keskusteluun. Julkisen palvelun ideaaliin kuuluu siis ajatus, että journalismi on lopulta vastuussa nimenomaan yleisölleen ("the public", Carey 2007, 12) ja on siten yhteiskunnallisesti hyödyllistä. Emme käytä tässä tekstissä julkisen palvelun käsitettä viittaaman vain julkisesti rahoitettuun journalismiin, sillä etenkin Suomessa eetos julkisesta palvelusta määrittää laajasti journalistien 
itseymmärrystä myös kaupallisessa mediassa (Heikkilä 2001; Koljonen 2013a, 45; Kunelius \& Ruusunoksa 2008).

Autonomisuuden normin mukaan journalismin tulee olla mahdollisimman riippumatonta ja itsenäistä yhteiskunnan muista instituutioista, jotta se voisi toteuttaa tehtäväänsä hyvin sekä pysyä omaleimaisena (Waisbord 2013, 43-47). Yksittäisen toimittajan kannalta autonomisuudella tarkoitetaan sitä liikkumatilaa, jota journalisteilla on tehdessään työtään - sekä suhteessa journalismin ulkopuolisiin toimijoihin, kuten vallanpitäjiin tai markkinoihin, että suhteessa toimitusorganisaatioiden sisäisiin toimijoihin, eli vaikkapa pomoihin ja kollegoihin (Löfgren-Nilsson 1999, MCDevitt 2003; Ahva 2010, 80-81). Länsimaisessa journalismissa autonomisuuteen yhdistyy läheisesti myös ajatus siitä, että journalismin liikkumavaraa tulee käyttää kriittiseen tarkasteluun, pimentoon jääneiden asioiden paljastamiseen (Hanitzsch 2007).

Eettisyys on monille professioille yleinen arvo. Journalismissa eettisyys ymmärretään sananvapauden pohjalta: journalismin tehtävänä on edistää sananvapautta, mutta tehtävän hoitamiseen tarvitaan vastuullisuutta, harkintaa ja itsesääntelyä (Koljonen 2013a, 85). Rakenteelliset tekijät, kuten lait ja eettiset koodistot, vaikuttavat osaltaan journalismin eettisyyteen, mutta toimittajille on annettu myös melko paljon liikkumavaraa omassa toiminnassaan: esimerkiksi Journalistin ohjeet jättävät tiaa tilannekohtaiselle harkinnalle (ks. esim. Mäntylä 2008). Virallinen eettinen koodisto ei siis yksinään määritä journalismin eettisyyttä, vaan koodisto on samalla tukipylväs, joka herkistää journalistit eettisyyden pohdintaan (Nordenstreng 1998, 131; Heinonen 1995, 6-7).

Objektiivisuus on puolestaan käsitys siitä, että journalismin tulee pyrkiä välittämään yleisölle mahdollisimman totuudenmukainen, tasapuolinen ja tosiasioita vastaava kuva. Vaikka objektiivisuus on tutkimuksellisena käsitteenä monimerkityksinen, käytännössä se kuitenkin ohjaa journalistien työtä ja määrittää heidän suhtautumistaan tietoon, sen keräämiseen ja välittämiseen (Koljonen 2013a, 69). Objektiivisuus on erittäin keskeisessä osassa länsimaisten journalistien itseymmärryksessä, jonka mukaan toimittajan omat subjektiiviset näkemykset eivät saa vaikuttaa tuotettuihin sisältöihin (Hanitzsch 2011). Tuoreen suomalaistutkimuksen mukaan toimittajien käsitys objektiivisuudesta on edelleen vahva, mutta se sisältää myös ajatuksen kriittisestä analyyttisyydestä, ei pelkästä mekanistisesta faktojen välittämisestä (Reunanen \& Koljonen 2014).

Viimeinen esiin nostamamme journalismin ydinarvo on ajankohtaisuus. Journalistista työtä ja sitä kautta toimittajien itseymmärrystä määrittää vahvasti ajatus journalismin nopeudesta, tuoreudesta ja ajan tasalla pysymisestä - onhan uutinen keskeinen journalistinen genre (Deuze 2005). Tämä arvo kumpuaa etenkin uutistyön arkisesta toiminnasta: uutisesta tulee "pelkkää informaatiota", ellei se täytä ajankohtaisuuden tavoitetta - ellei toimittaja pysty keräämään, käsittelemään ja välittämään tietoa eteenpäin nopeasti (Tuchman 1973, 118). Tämän vuoksi nopeuskin on journalistinen hyve (Juntunen 2009).

Annamme tässä artikkelissa journalisteille mahdollisuuden arvioida ammattiaan ja sen muutosta ja tarkastelemme, millaiseen rooliin yllä esitetyt ydinarvot tässä arvioinnissa asettuvat. Käsittelemme siten journalistisen professionalismin diskursiivista rakentumista itseymmärryksen näkökulmasta. 


\section{Tutkimusaineisto ja menetelmät}

Suomalaisten toimittajien itseymmärryksen tutkimukselle on päivittämisen tarvetta, sillä viimeisin kattava suomalainen toimittajakysely on tehty vuonna 2007 (Jyrkiäinen 2008). Vuosina 2013-2014 toteutettu tutkimuksemme sisältää sekä määrällisen kyselyaineiston (366 vastaajaa) että laadullisia ryhmähaastatteluita (19 osallistujaa), joissa kattava otos suomalaistoimittajia arvioi journalismia ja omaa ammatillisuuttaan digitalisoituvassa mediamaisemassa 2010-luvulla.

Tämän artikkelin taustalla on kansainvälinen Worlds of Journalism Study -hanke (WJS), jossa arvioidaan ja vertaillaan journalismin tilaa, journalistien toimintamahdollisuuksia ja ammatillista omakuvaa maailmanlaajuisesti'. WJS-tutkimuksessa - ja siksi myös tässä Suomen osa-aineistossa - keskitytään yksinomaan ammattijournalisteihin: palkkasuhteisiin toimittajiin ja freelancereihin, jotka ansaitsevat journalismista vähintään puolet tuloistaan ja jotka tekevät työssään itsenäisiä journalistisia päätöksiä. Lisäkriteerinä on työskenteleminen mediaorganisaatiossa, joissa on oma toimitus ja itsenäisesti tuotettuja uutisia sekä muita journalistisia juttuja.

Määrälliseen lomakekyselytutkimukseen pyrimme saamaan edustavan otoksen suomalaistoimittajia. Haarukoinnin perusteella² arvioimme, että yllä esitetyt kriteerit täyttäviä toimittajia on Suomessa yli 7700. Tältä pohjalta otoskooksi määritettiin 95 \%:n luottamustasolla ja 5 \%:n otantavirhettä käyttäen 366 journalistia. Kyselyhaastateltavien valinnassa käytettiin ositettua otantaa kahdessa vaiheessa. Ensin määriteltiin haarukoinnin pohjalta haastateltavien määrällinen jakauma välineittäin ja työsuhteen mukaan (ks. taulukko 1). Tämän jälkeen valittiin vastaajat ottamalla huomioon sekä medioiden alueellinen jakauma että median koko suhteessa muihin saman välineen medioihin. WJS-projektin lähtökohtana oli se, että yhdestäkään mediasta ei saisi tulla enempää kuin viisi vastaajaa. Tästä säännöstä kuitenkin poikettiin muutamassa tapauksessa, jotta eri medioiden väliset kokoerot tulisivat selkeästi esille. ${ }^{3}$ Yksittäiset haastateltavat valikoituivat lopulta vastaajiksi pääosin toimitusten johdon kautta. ${ }^{4}$

Taulukko 1. Haastateltujen toimittajien jakauma.

\begin{tabular}{|l|l|l|l|}
\hline Ryhmä & Työsuhteiset & Freelancerit & Yhteensä \\
\hline Sanomalehdet & 145 & 9 & 154 \\
\hline Aikakauslehdet & 55 & 45 & 100 \\
\hline Radio & 44 & 3 & 47 \\
\hline Televisio & 33 & 6 & 39 \\
\hline Nettiuutispalvelut & 16 & 0 & 16 \\
\hline Uutis- ja kuvatoimistot & 9 & 1 & 10 \\
\hline Yhteensä & 302 & 64 & 366 \\
\hline
\end{tabular}


Useimmat eli 57 \% kyselyyn vastanneista määrittelivät itsensä ns. rivitoimittajiksi, mutta aineistossa on edustettuna muitakin toimenkuvia, kuten erikoistoimittaja (14 \%), toimituspäällikkö (7 \%) ja tuottaja (6 \%). Noin neljäsosa kaikista vastanneista katsoi nykyisessä toimessaan olevansa joko ylemmän tai keskiportaan johtotehtävissä. Eniten aineistossa oli valtakunnallisissa medioissa työskenteleviä ( $57 \%$ ), ja enemmistö oli työssä päivä- tai aikakauslehdissä (yhteensä 58 \%). Useimmat työskentelivät pysyvässä ( $87 \%$ ) ja kokoaikaisessa (78 \%) työsuhteessa. Freelancereita haastatelluista oli $17 \%$, määräaikaisia $13 \%$ ja osa-aikaisia 4 \%. Naisvastaajia oli haastatelluista 55 \% ja loput miehiä. Toteutunut otos vastaa melko hyvin ammattikunnan yleistä jakaumaa eri välineissä. ${ }^{5}$

Kyselytutkimus toteutettiin puhelimitse kevään ja kesän 2013 aikana standardoidun lomakkeen avulla ${ }^{6}$. Kysymykset koskivat toimittajien taustaa, ammattiroolikäsityksiä, toimittajien ammatillista vapautta, toimintatapojen eettisyyttä, työhön vaikuttavia tekijöitä ja tekijöissä tapahtuneita muutoksia viimeisen viiden vuoden aikana. Vastaukset koodattiin SPSS-ohjelmassa, ja niiden pohjalta tuotettiin määrällisiä tuloksia vastausten jakaumista sekä eri vastaajaryhmien ${ }^{7}$ ja annettujen vastausten välisistä korrelaatioista. Tässä artikkelissa keskitymme pääosin aineiston tuottamaan yleiskuvaan.

Määrällisellä kyselytutkimuksella arvelimme pääsevämme kartoittamaan yleislinjoja ammattikunnan yhteisestä arvopohjasta. Koska lomake vastausvaihtoehtoineen oli ennalta strukturoitu, vaihtoehdot luonnollisesti määrittivät toimittajien tulkintoja ${ }^{8}$. Siksi tutkimuksessa kerättiin määrällisen aineiston tueksi laadullinen ryhmähaastatteluaineisto keväällä 2014. Laadullista haastattelumateriaalia hyödynnetään tässä artikkelissa täydentämässä ja tarkentamassa kyselytutkimuksen tuloksia, etenkin niissä esiintyviä ristiriitaisuuksia.

Laadullinen osuus toteutettiin toimittajien ryhmähaastatteluilla viidessä toimituksessa: alueellisessa uutislehdessä, julkisrahoitteisessa mediassa, kaupallisessa televisiossa, yleisaikakauslehdessä sekä alueellisen uutislehden verkkotoimituksessa. Lisäksi koottiin erikseen ryhmä paikallistoimittajista. Haastatteluihin osallistui kerralla kahdesta viiteen henkeä ja kaikkineen 19 toimittajaa uran eri vaiheista ${ }^{9}$. Miehet (10) ja naiset (9) ovat aineistossa edustettuina tasapuolisesti. Temaattisissa ryhmähaastatteluissa toimittajille esitettiin kyselytutkimuksen tuloksia ja niihin kytkeytyviä ajankohtaisia uutistekstejä keskustelun pohjaksi. Teemat olivat siten samoja kuin kyselytutkimuksessakin, mutta niitä myös kohdennettiin välineittäin ja sovellettiin vapaasti sen mukaan, mistä toimittajat itse keskustelivat. Kukin ryhmähaastattelu kesti tunnista puoleentoista; sen jälkeen ne litteroitiin, luettiin ja teemoiteltiin laadullisen sisällönanalyysin keinoin. Ryhmähaastattelujen sisällöistä johtuen teemoittelussa korostuvat samat aiheet kuin kyselytutkimuksessa, mutta ryhmähaastattelujen laadullisessa analyysissa kiinnitettiin huomiota etenkin sellaisiin merkitystiivistymiin, joissa kyselytutkimuksen tulosten kanssa oltiin yhtäältä selvästi samanmielisiä ja toisaalta selkeästi erimielisiä.

Aineistokokonaisuudessamme on omat rajoituksensa. Emme voi sen avulla saavuttaa kattavaa kuvaa journalismiprofession diskursiivisesta rakentumisesta, sillä valitsemamme näkökulma ei avaa suoraa näkymää esimerkiksi työn tekemisen arkisiin käytäntöihin. Emme myöskään voi avata tapoja, joilla rakenteelliset seikat vaikutta- 
vat professionalismiin. Lähestymistapamme kuitenkin antaa mahdollisuuden käsitellä työkäytäntöihin ja rakenteisiin liittyviä kysymyksiä journalistien oman tulkinnan kautta. Lisäksi journalisteille avautuu tilaisuus toimia oman ammatillisuutensa asiantuntijoina: pohtia omaa työtään, sen arvopohjaa ja siihen kohdistuvia muutoksia.

\section{Työhön vaikuttavat tekijät ja muutokset: Teknis-taloudelliset resurssipaineet kasvaneet}

Aloitamme tulosten käsittelyn kuvaamalla toimittajien kokemuksia työstään, toimintaympäristöstään ja etenkin niiden muutoksista. Kyselytutkimuksessa toimittajilta kysyttiin näkemyksiä siitä, kuinka suuri merkitys eräillä toimituksen sisäisillä ja ulkopuolisilla ryhmillä sekä vaikuttajatahoilla tai muilla tekijöillä on heidän työhönsä. Eri tekijöiden vaikutusta journalistien työhön arvioitiin tiivistettynä taulukkoon 2 seuraavasti:

Taulukko 2. Toimittajien käsitykset työhön vaikuttavista tekijöistä.

Vähiten vaikutusta:

Sensuuri ${ }^{10}$, toimituksen ulkopuoliset institutionaaliset toimijat (armeija, poliisi, eturyhmät, poliitikot, viranomaiset), talous (mainonta ja mainostajat, omistajat, liike-elämä, tuotto-odotukset, uutisorganisaation taloudellinen johto, suhdetoiminta ja PR), läheiset (ystävät, tutut, perhe)

Enemmän vaikutusta:

Kilpailijat, yleisö (palaute, tutkimustieto), vertaiset, henkilökohtaiset lähdesuhteet, pääsy viranomaistietoihin

Eniten vaikutusta:

Esimiestyö ja johto, omat arvot ja uskomukset, toimituksen linja, aikarajoitteet ja resurssit, medialait ja säännökset, journalistinen etiikka ${ }^{11}$

Arvioissa esiin nousee ensinnäkin politiikan, liike-elämän ja muiden instituutioiden vähäiseksi arvioitu vaikutus toimittajien toimintaan. Siten vastaukset korostavat toimittajaprofession rakenteellista autonomiaa, eli mahdollisuutta tehdä työssä toimitusorganisaation ulkopuolisista tahoista riippumattomia päätöksiä. Yksilöllinen autonomia, eli mahdollisuus tehdä itsenäisiä päätöksiä organisaation sisällä ja omassa toimenkuvassa, ei näytä vastauksissa yhtä vakaalta, sillä organisaation linjalla ja esimiehillä koettiin olevan melko paljon vaikutusta työhön. Tämä lienee heijastusta suunnitelmallisuuden ja ennakoivan toimituskulttuurin sekä johtamisen yleistymisestä (Koljonen 2013b). Arvioita tulkittaessa merkitystä on myös sillä, ovatko toimittajat vastanneet kysymyksiin ihanteiden vai käytäntöjen näkökulmasta. Vastausta ei varmuudella tiedetä, mutta kyselytutkimuksessa annetut muut vastaukset ja laadulliset ryhmähaastattelut antavat aihetta ajatella, että toimittajien vastauksia on ohjannut hyvin sisäistetty ja jo toimittajakoulutuksessa omaksuttu normatiivinen käsitys autonomisesti toimivasta journalistista, jonka työhön ja työn jälkeen ulkoiset tekijät eivät saisi vaikuttaa (Herkman 2009, 47; Väliverronen 2009). 
Käytännön tilanne esimerkiksi autonomisuuden suhteen on usein monisyisempi kuin sisäistetyt ihanteet yksin antavat olettaa. Tämä käy ilmi, kun tarkastellaan toimittajien arvioita journalismiin viimeisenä viitenä vuotena kohdistuneista muutoksista. Kaikkien kysyttyjen tekijöiden ${ }^{12}$ vaikutuksen arvioitiin kasvaneen. Vaikkei vaikutuksen lähtötasoa tai nykyistä määrää tiedetäkään, tulos on sinänsä merkittävä: se kertoo professioon kohdistuvista kasvavista odotuksista, joiden puristuksessa autonomiaa halutaan pitää yllä. Yksittäisten tekijöiden osalta tuloksia on tiivistetty taulukkoon 3.

Taulukko 3. Toimittajien käsitykset journalismiin vaikuttavissa tekijöissä tapahtuneesta muutoksesta. ${ }^{13}$

\begin{tabular}{|l|r|r|r|}
\hline $\begin{array}{l}\text { Journalismiin vaikuttavia tekijöitä, } \\
\text { muutos viimeisen 5 vuoden aikana }\end{array}$ & $\begin{array}{r}\text { Vaikutus } \\
\text { kasvanut (\%) }\end{array}$ & $\begin{array}{r}\text { Ei } \\
\text { muutosta (\%) }\end{array}$ & $\begin{array}{r}\text { Vaikutus } \\
\text { vähentynyt (\%) }\end{array}$ \\
\hline Sosiaalinen media & 97 & 2 & 0 \\
\hline Kilpailu & 94 & 4 & 2 \\
\hline Käyttäjien tuottama sisältö & 93 & 6 & 1 \\
\hline Tulospaineet & 91 & 8 & 1 \\
\hline Yleisön osallistuminen uutistuotantoon & 82 & 15 & 2 \\
\hline Sensaatiohakuisuus & 71 & 24 & 4 \\
\hline & & & 6 \\
\hline Mainonta ja mainostajat & 62 & 24 & 9 \\
\hline Suhdetoiminta, PR & 42 & 43 & 30 \\
\hline Eettiset normit & 32 & 36 & \\
\hline
\end{tabular}

Tuloksissa erottuvat ensinnäkin teknologisen muutoksen haasteet. Erityisesti tämä näkyy verkon synnyttäminä uusina vaatimuksina: journalismiin vaikuttavista tekijöistä viimeisen viiden vuoden aikana eniten olivat merkitystään kasvattaneet sosiaalinen media ja yleisön tuottama sisältö. Asiassa ei ole mitään yllättävää, sillä lehdet ja perinteiset sähköiset viestimet ovat viime vuosina siirtyneet verkkoon ja digitaaliseen muotoon - esimerkiksi lehdet toden teolla vuosista 2006-2007 lähtien (Juntunen 2010) - ja ottaneet sittemmin käyttöön erilaisia sosiaalisen median palveluita (Heinonen 2008; Vainikka ym. 2013). Samalla ne ovat alkaneet miettiä, kuinka yleisö voisi osallistua sisällöntuotantoon ja kuinka yleisö saataisiin pysymään median kuluttajina uuden teknologian avulla.

Yleisön entistä suuremmalla huomioimisen tarpeella voi kuitenkin olla vaikutuksensa toimittajien työn autonomian kannalta. Toimittajat ovat selittäneet työn muutoksia - esimerkiksi nopeus- ja moniosaamisvaatimusten kasvua - teknologisella kehityksellä myös aiemmissa tutkimuksissa (Jyrkiäinen 2008; Nikunen 2011). Toteuttamistamme ryhmähaastatteluista on havaittavissa, että teknologia vaikuttaa nykyisin toimittajiin ja journalismiin tätäkin moniulotteisemmin, kun digitaalisen teknologian sovellusten käyttö on läpäissyt toimitukset kauttaaltaan. Yhtäällä teknologia tarjoaa toimittajalle mahdollisuuden tehdä työnsä aiempaa monipuolisemmin, helpommin ja 
paremmin, kun taas toisaalla se hajottaa keskittymistä olennaiseen ja vaikeuttaa työtehtävien hoitoa. Yhtä kaikki, teknologiaan - ja erityisesti verkon logiikkaan - on vain sopeuduttava. Erään toimittajan sanoin:

Toi netti on sellanen jolleka ei yksinkertasesti voi mitään ku se on iso historiallinen voima vähän niin ku kirjapaino. (Ryhmähaastattelu, televisio)

Mediatalojen johdolta kuitenkin kaivattiin ryhmähaastatteluissa välineestä riippumatta selkeitä suuntaviivoja journalistisen työn organisoinniksi muuttuneessa teknologisessa tilanteessa. Nyt johdon vaatimukset toimituksen ja uutistuotteen teknologisesta ja sisällöllisestä kehittämisestä valuvat toimittajien suuntaan ja näkyvät usein lisääntyvinä mutta jäsentymättöminä työtä koskevina vaatimuksina.

Kritiikki johtamisen jäsentymättömyydestä liittyy toimittajien kokemiin resurssivähennyksiin. Kyselytutkimuksessa journalistit arvioivat keskimääräisen työaikansa kasvaneen samalla, kun he käyttivät juttujen tiedonhankintaan ja taustoitukseen yhä vähemmän aikaa. Samassa ajassa täytyy myös saada aikaan enemmän kuin ennen (vrt. Davies 2008; Jyrkiäinen 2008; Nikunen 2011). Aikateema ja kiire nousivat esiin myös ryhmähaastatteluissa. Kokemuksia oli muun muassa siitä, että omaa määriteltyä erikoisalaa ei työssä pääse toteuttamaan, koska sille ei muilta töiltä jää aikaa. Resurssien vähenemisen lisäksi tämä on seurausta suuntauksesta, jossa on siirrytty asiantuntijatoimittajista yleistoimittajuuteen (Nikunen 2011, 47). Toimittajat sanoivat perehtyvänsä jopa työnsä keskeisiin sisältöihin vapaa-ajalla, ja esimerkiksi sosiaalisen median käyttö ja sen opettelu on usein oman harrastuneisuuden varassa.

Digitalisoituvassa toimintaympäristössä kiire näyttää olevan ammatillisesti hyväksytty puhetapa käsitellä ajankohtaisuuden arvoa. Ajankohtaisuuden ja nopeuden vaatimukset journalistisessa työssä johtavat kiireeseen, jota toimittajat yhtäältä kertoivat säännöllisesti kokevansa (vrt. Jyrkiäinen 2008). Toisaalta kiireestä selviytymisessä korostuvat sujuva jutuntekotaito ja kyky kestää aikapaineita, siis toimittajan työssä olennaiset ominaisuudet, minkä vuoksi kiirettä työssä ei koeta erityisenä ongelmana. Kaikki toimittajat eivät ryhmähaastatteluissa allekirjoittaneetkaan kokemuksia kiireestä, vaan asia nähtiin yksinomaan työsuunnitelmallisena ja omiin työskentelykykyihin liittyvänä kysymyksenä. Työtään suunnittelemalla on mahdollista sekä tuottaa ajankohtaista ja nopeatempoista journalismia että välttää kiireen tuntua. Jotkut toimittajat kuitenkin kertoivat tarpeesta tinkiä omasta vaatimustasosta voidakseen vastata kiireeseen, mikä puolestaan voi aiheuttaa turhautumista ja tavoitteista luopumista:

[S]ä oot vaan vähän väsyneempi ja vähän useemmin vähän pettyny siihen että olisinpa halunnu penkoa tuota vähän enemmän ja kirjottaa tota juttuu, viilata sitä vielä vähän pidempään. Sitten se vähän turhauttaa koska kunnianhimoissaan haluis silleen tehä parempaa mutta se että, eihän nyt se että sulla on enemmän kiire saa sua ajattelemaan siitä eri tavalla että okei, nyt voidaan tehdä ihan eri tav-, kääntää sitä että (...) mun ei tarvi olla enää vastuullinen. Että se on ihan mahoton ajatus. (...) Mun mielestä se on 
ihan selviö että se pysyy se meidän ammatti-identiteetti ihan samana siellä pohjalla. Jos se muuttuu niin sit todennäkösesti ei enää haluu tehäkään näitä hommia.

(Ryhmähaastattelu, aikakauslehti)

Teknologisen muutoksen ohella toinen merkittävä kyselytutkimuksen tuloksista esiin nouseva seikka on talouden kasvava merkitys. Tämäkään ei ole yllätys: mediakilpailun on Suomessa nähty kasvaneen 1990-luvulta saakka (Pietilä 2007, luku 5), ja tilannetta ovat viime vuosina kiristäneet niin verkkojournalismin kasvu kuin journalismin kiihtyvä kilpailu ei-journalistisesti tuotettujen sisältöjen kanssa. Seurauksena on ollut journalismin kannattavuusongelmia, jotka ovat johtaneet toimittajien irtisanomisiin tai poistumiseen työelämästä eläkepakettien kautta (Nikunen 2011; Honkonen \& Lankinen 2012). Muutokset haastavat myös toimittajien autonomisuusajattelua, mikä näkyy tekemässämme kyselytutkimuksessa: vaikka taloudella ei (haluta) nähdä olevan vaikutusta työhön (Taulukko 2, taloudella "vähiten vaikutusta"), tulkitaan sen vaikutuksen esimerkiksi kilpailun ja tulospaineiden muodossa kuitenkin viime vuosina kasvaneen (Taulukko 3, esim. 91 \% kokee tulospaineiden kasvaneen).

Laadullisissa ryhmähaastatteluissa talousasiat puhututtivat toimittajia erityisen paljon, ja kyselyn havainnoille saatiin vahvistusta. Talouden ja kilpailun sanottiin vaikuttavan jopa suoraan journalismin sisältöihin. Valtakunnallisessa mediassa tunnistettiin suhdetoiminnan ja PR:n merkityksen kasvu (vrt. myös Davies 2008; Väliverronen 2009; Herkman 2009; Nikunen 2011): tiedotevirta organisaatioista mediaan on kasvanut (vrt. Juntunen 2011), samalla kun organisaatioista on yhä vaikeampaa saada suoria vastauksia toimittajien itse asettamiin kysymyksiin. Osa paikallistoimittajista puolestaan näki mainostajien vaikutuksen journalismin sisältöihin jopa keskeisenä ongelmana.

[S]e on ristiriidassa että mitä voi kertoo ja kenestä voi kertoo. Sillon kun se ei palvele ilmottajaa, niin tänä päivänä ollaan hukassa. Niitä tiettyjä asioita ei sanota silloin kun se on, lehden tärkeimpiä ilmottajia. (Ryhmähaastattelu, paikallislehdet)

Talouden vaikutus näkyi myös välillisesti. Ryhmähaastatteluissa mediaorganisaatioiden johdon koettiin usein "poukkoilevan trendien perässä" ilman johdonmukaista ja pitkäjänteistä käsitystä siitä, kuinka pärjätä mediakilpailussa. Toimittajien mukaan johto ei ymmärrä, ettei kaikkiin trendeihin ole mahdollista vastata eikä toimittajien työtaakkaa loputtomasti lisätä ilman, että työn laatu ja journalismin autonomisuus alkavat jossain vaiheessa kärsiä (vrt. Jyrkiäinen 2008, 36-38).

Mua häiritsee sillon kun se [talouspaine] syö sellaista pitkäjänteisyyttä sen koko lehden tekemisestä, ja tulee sellaista poukkoilua. Tehdään näin ja ei tehdäkään ja, sun pitää nyt ruveta tekee näin ja sitten että, no ei tällä oikeesti ollu mitään väliä taas teenks mä näin vai näin. Että kun koitetaan seurata niitä pylpyröitä ja, otaksua että ihmiset haluu nykyään tätä ja lukijat toivoo nyt just tätä ja, ilmottajat tätä niin kyllä meijän nyt pitää olla tuolla. Sitten kun sä kuitenkin tiiät paljon se sun käytännön työ vie sitä aikaa, jos sä koitat sen hyvin hoitaa. Se ei muutu siitä mihinkään. (Ryhmähaastattelu, paikallislehdet) 
Taloudellisten tuottavuusvaatimusten aiheuttamia ongelmia toimittajat näkivät erityisesti verkkojournalismissa, jossa mediaorganisaatioiden mainittiin yrittävän hankkia klikkauksia keveiden ilmiöjuttujen ja raflaavien otsikoiden turvin. Tilannetta pahentaa ryhmähaastatteluaineiston mukaan se, että verkkojournalismia tekevät usein mediatalon kokemattomimmat toimittajat vähäisen sisäisen avun turvin. Erikoistuneessa verkkotoimituksessa näkemyksiä ei tosin allekirjoitettu, vaan korostettiin toiminnan suunnitelmallisuutta, vastuullisuutta ja eettisyyttä.

Tästä koko hommasta kismittää se että sitä verkon roolia ja suunnittelua ja näitä valintoja ei ole kirjoitettu auki, ja niitä ei valvota. Se on semmonen ihmeellinen villi länsi mihin suhtaudutaan kauheen huolettomasti. Mikä on täysin väärä suhtautumistapa ku ne jutut leviää siellä ikuisuuksien meidän brändin alla. Mun mielestä meidän pitäis olla paljon enempi huolissaan meidän brändistä ja meidän uskottavuudesta. (Ryhmähaastattelu, aluelehti)

Kuten sitaatista näkyy, osassa medioista vaatimukset näkyvät myös suorana "brändipuheena" siitä, missä media menee suhteessa kilpailijoihin. Vaikka vastakkainasettelu mediayhtiöiden voittoa tavoittelevan johdon (taloudelliset tekijät) ja työtään yhä etupäässä journalistisista lähtökohdista (kulttuuriset tai ammatilliset tekijät) käsin tekevien toimittajien välillä ei ainakaan näyttäisi kaventuneen viime vuosina (vrt. Nikunen 2011, 113), on selvää, että ammatilliseen itseymmärrykseenkin on kulkeutunut käsitys brändeistä ja kilpailusta (vrt. Lehtonen 2013).

Kaikkiaan toimittajien kokemien vaikutusten ja muutostrendien tarkasteleminen korostaa taloudellis-teknologisten muutosten (vrt. Kunelius \& Ruusunoksa 2008) vaikutusta yksittäisten toimittajien työlle. Tässä muutoksessa etenkin ajankohtaisuus näyttäytyy merkittävänä arvona, koska se auttaa ymmärtämään ja käsittelemään tapahtuneita muutoksia, kuten verkon ja kilpailun mukanaan tuomia aikapaineita. Autonomisuus puolestaan näyttäytyy arvona, josta halutaan ristiriitojenkin uhalla yhä pitää kiinni myös näiden muutosten keskellä. Yleisemminkin toimittajat haluavat uskoa ammatti-ihanteisiin, koska niiden avulla voidaan perustella itselle työn tärkeyttä ja mahdollisuutta tehdä ulkoisista paineista huolimatta edelleen yhteiskunnallisesti merkittävää työtä:

Se on ehkä siinä että minkä takii siitä ihanteesta haluu pitää kiinni koska ainakin, omassa tuttavapiirissä ja myös itsellä se lähteminen alalle on perustunu johonkin semmoseen että, haluan tietää haluan kertoa muillekin ja haluan omalta osaltani tehdä jotain sen eteen että, sosiaalisesti heikommassa asemassa olevilla ehkä voisi mennä joskus vähän paremmin. Jos multa viedään kaiken taustalta se pois niin en mä oikeestaan nää et haluunks mä olla toimittaja.

(Ryhmähaastattelu, aluemedia) 


\section{Kestäviä arvoja: Autonomisuus, objektiivisuus ja julkinen palvelu}

Kyselytutkimuksen vastaukset antoivat lähes kautta linjan viitteitä siitä, että autonomisuuden lisäksi objektiivisuuden ja julkisen palvelun arvoista ei haluta muutostenkaan keskellä irtautua, vaikka arvoja kuitenkin käytännön työssä myös lavennetaan. Asia käy ilmi kysymyksistä, joissa toimittajia pyydettiin arvioimaan, kuinka tärkeinä viisiportaisella asteikolla ${ }^{14}$ he pitivät työssään journalistin erilaisia tehtäviä ja rooleja. Taulukkoon 4 on koottu viisi tärkeintä ja vähiten tärkeää tehtävää.

Taulukko 4. Toimittajien arviot eräiden tehtävien tärkeydestä työssään.

\begin{tabular}{|l|l|l|}
\hline Journalistin tehtävä & \multicolumn{2}{|l|}{ Tärkeys } \\
\hline & $\begin{array}{l}\text { Ei kovin / ei lainkaan } \\
\text { tärkeää (\%) }\end{array}$ & $\begin{array}{l}\text { Hyvin / Erittäin } \\
\text { tärkeää (\%) }\end{array}$ \\
\hline Raportoida asiat todenmukaisesti & 2 & 92 \\
\hline Olla riippumaton tarkkailija & 2 & 91 \\
\hline Analysoida ajankohtaisia asioita & 3 & 86 \\
\hline Kertoa tarinoita maailmasta & 4 & 77 \\
\hline Antaa ihmisten ilmaista mielipiteensä & 10 & 69 \\
\hline & & 21 \\
\hline $\begin{array}{l}\text { Kannustaa osallistumaan poliittiseen } \\
\text { toimintaan }\end{array}$ & 48 & 14 \\
\hline Määrittää poliittista agendaa & 53 & 10 \\
\hline Toimia hallituksen vastavoimana & 65 & 0 \\
\hline Tukea hallituksen linjaa & 95 & 1 \\
\hline $\begin{array}{l}\text { Luoda myönteistä kuvaa poliittisista } \\
\text { päättäjistä }\end{array}$ & 96 & \\
\hline
\end{tabular}

Tärkeimmiksi tehtäviksi koettiin todenmukainen raportointi asioista, riippumattoman tarkkailijan rooli ja ajankohtaisten tapahtumien analysointi. Kannatusta saivat myös poliittisen johdon $\left(64 \%{ }^{15}\right)$ ja liike-elämän edustajien (56 \%) valvonta ja vahtiminen. Samat tehtävät saivat eniten mainintoja myös, kun toimittajia pyydettiin lomakkeen avovastauksissa nimeämään ne journalistin roolit, joiden tulisi olla työssä tärkeimpiä. Vastauksissa vaikuttavat siis keskeisesti sekä objektiivisuuden että autonomisuuden arvot. Lisäksi niissä korostui myös professionalismin demokratiaa edistävä julkisen palvelun arvopohja: mielipiteiden ilmaisemisen mahdollistaminen (69\%), monimuotoisuuden edistäminen ( $67 \%$ ) ja tiedon tarjoaminen ihmisille poliittista päätöksentekoa varten (63\%).

Suomalaistoimittajien ammattikuvassa korostuu siis varsin selvästi ns. puolueettoman vahtikoiran rooli, jota voi kuvata länsimaisen journalistin prototyypiksi (Hanitzsch 
2011, 485). Näkemykset toimittajan työn tehtävistä myös kuvastavat vahvasti korkean modernin journalismiksi kuvattua itseymmärrystä (Hallin 1992; Kantola 2011, 119-125; Koljonen 2014), jota ohjaa etenkin objektiivisuuden arvo. Siinä journalismin ja journalistin tehtäviksi katsotaan erityisesti totuudenmukainen tiedonvälitys sekä kansalaisten informointi, johon kuuluu faktojen ja mielipiteiden erottelu (Koljonen 2013a, 89). Korkean modernin arvoja on kuitenkin haastettu jo 1980-luvulta saakka yhteiskunnallisten, (media)taloudellisten ja teknologisten muutosten vuoksi (Hallin 1992). Tämän kehityksen seurauksena korkean modernin journalismin rinnalle - ja osin kilpailijaksikin - on noussut notkean modernin ${ }^{16}$ journalismi (Kantola 2011), jossa ammatillisuus jäsentyy yhä enemmän suhteessa yleisön huomioimiseen ja ajankohtaisuuteen (vrt. Koljonen 2013a, 90).

Kyselytutkimuksen toimittajaroolia käsittelevät tulokset osoittavat aiempien havaintojen tapaan murrostilaa (vrt. Kantola 2011; Koljonen 2013a): korkeaan moderniin pohjautuvan arvoytimen rinnalle on tullut yleisösuhdetta korostavia, notkeita aineksia. Toimittajien arvioissa esimerkiksi tarinoiden kertominen on tehtävänä mennyt yleisön valistamisen ( 50 \%) ohitse. Selkeimmin tehtävänsä tarinankertojiksi mielsivät aikakauslehtijournalistit, joiden työ onkin nähty edelläkävijänä journalismin tarinallisuuden kehityksessä (Töyry 2009; Holmes \& Nice 2012).

Laadullisissa haastatteluissamme suomalaistoimittajat korostivat korkeiden ja notkeiden arvojen lomittumista. Ydinarvoihin ikään kuin sisällytetään notkeita toimintatapoja. Esimerkiksi tarinallisuus nähtiin ennen muuta ammattitaitona, jonka avulla objektiivisuuden hallitsemaa journalismin normatiivista ydintä pidetään yllä. Tarinallisuus on siis toimittajille nykyjournalismin formaatti: asiat, puolueettomuutta korostavat uutisetkin, on kerrottava tapausten ja tarinoiden kautta, jotta ne olisivat yleisölle kiinnostavia ja houkuttelevia (vrt. Heikkilä ym. 2012; Costera Meijer 2013). Toimittajat luottavat siihen, että yleisö osaa erottaa faktat, henkilökohtaisemmat tapaustarinat ja toimittajien kommentit toisistaan:

V1: Mä ehkä uskon kuitenkin että yleisö ja katsoja on sen verran valveutunu että se pystyy erottamaan sen tarinan. Että tää nyt on yksi case ja se vois olla joku toinen case mutta monesti (...) mennään tarinan kautta ja haetaan niitä caseja siihen. (...) Ja totta kai siinä pyritään myös miettimään sitä että saadaan myös vastapuoli siinä puhumaan ja ettei se oo aina ainakaan se yksi ja sama tai saman puolen tekijä joka puhuu ja toimii.

V2: Ja sehän on vaan yksi tapa kertoa niitä asioita. (...) Ei se mun mielestä vie riippumattomuutta pois vaan sillon vaan kerrotaan uutisia sillä tavalla että hei me yritetään saada nää ihmiset kiinnostuun niistä uutisista mitä me kerrotaan. Se tapa on tarina tai millä se saadaan kerrottua koska selkeetähän on että kukaanhan ei jaksa komiteamietintöjä lukee. (Ryhmähaastattelu, televisio)

Tarinallisuuden kokeminen tärkeäksi antaa osaltaan viitteitä myös siitä, että ydinarvo julkisen palvelun ideaalista on laventunut hyvän julkisuuden rakentamisesta kohti laveampaa yleisön palvelemisen ajatusta. Tähän viittaavat myös eräät suurim- 
miksi muutoksiksi koetut tekijät: sosiaalisen median, käyttäjien tuottamien sisältöjen ja yleisön osallistumisen vaikutuksen koetaan journalismissa viimeisen viiden vuoden ajan vahvasti kohonneen (ks. Taulukko 3). Yleisölähtöisyydestä ja lukijoiden "lähelle pääsemisestä" todistavat myös useat suomalaiset journalismin tutkimukset (Hujanen 2009; Lehto 2006; Ahva \& Pantti 2015).

Kuitenkin kyselytutkimuksessa toimittajien mielipiteitä eniten jakaneissa tehtävissä olivat mukana juuri palvelujournalismiin ja mediatalojen taloudellisten menestystarpeiden täyttämiseen liittyvät roolit: viihdyttävyys (jonkin verran tärkeää 42 \%), neuvojen tarjoaminen arkeen (40 \%) ja yleisöjen houkuttelu (37\%). Ryhmähaastatteluissa yleisön ja sen palvelun merkitystä ei silti mitenkään kielletty: työtä tehdään yleisöä varten, ja se pitää saada kiinnostumaan journalismista. Siksi yleisöä kuunnellaan ja asioita koetetaan esittää tarinoiden ja viihdyttävyydenkin avulla niin, että juuri oman välineen yleisön on ne mahdollista käsittää (vrt. Machill, Köhler \& Waldhauser 2007). Toimittajat kuitenkin kritisoivat omien ja muiden medioiden käyttämiä yleisön liikoja houkuttelu- ja viihdyttämisyrityksiä (ks. myös Jyrkiäinen 2008, 50, 57; Nikunen 2011). Julkisen palvelun täydellistä muuttumista markkinaehtoiseksi kuluttajakeskeisyydeksi ei siten haluta omaksua.

Edellä mainittujen toimittajan tehtävien tapaan toimittajien mielipiteitä kyselytutkimuksessa jakoivat yhteiskunnalliseen vaikuttamiseen liittyvät tehtävät: vaikuttaminen yleiseen mielipiteeseen (jonkin verran tärkeää $39 \%$ ), yhteiskunnan muuttaminen (37\%) tai Suomen kehityksen tukeminen (40 \%). Aktiivisen liikkeellepanijan rooli (vrt. Hanitzsch 2011) näyttää siis olevan suomalaisten journalistien työssä selkeästi alisteinen autonomiaan ja objektiivisuuteen perustuvalle tiedonvälitystehtävälle. Havaintoa tukee se, että poliittisen agendan määrittely ja ihmisten kannustaminen poliittiseen toimintaan nähtiin kyselyssä hyvin vähämerkityksisinä. Journalistit eivät etenkään halua myötäillä poliitikkoja ja valtapolitiikkaa, sillä kaikista vastenmielisimpinä nähtiin hallituksen linjan tukeminen ja myönteisen kuvan luominen poliitikoista. Reunasen (2014) mukaan suomalaistoimittajien poliittista identiteettiä kuvastavatkin sitoutuminen rationalistiseen, järkiperäiseen ja ongelmanratkaisuun tähtäävään politiikkakäsitykseen, neutraali suhtautuminen politiikkasisältöihin ja aktiivinen erottautuminen poliittisista ryhmittymistä.

Ryhmähaastatteluissamme toimittajat näkivätkin yksiselitteisesti, ettei toimittajien puoluelehtiä lukuun ottamatta tulisi ajaa minkäänlaista poliittista intressiä työtä tehdessään. Toimittajat eivät edes välttämättä mieltäneet itseään vallankäyttäjiksi, vaan omaa toimittajuutta hahmotettiin ammatillisuuden toiminnallisella tasolla konkreettisina työsuorituksina, joita tehdessä ei ole aikaa syvällisemmin pohtia, millaisia laajempia vaikutuksia omalla tekemisellä mahdollisesti on. Erityisesti nuoremmat toimittajat näkivät asemansa näin.

Vallan vahtikoira kuulostaa kyllä semmoselle, mihin ei oo aikaa, mahdollisuuksia eikä välttämättä ymmärrystäkään. Se on, nopeesti saa jonkun uutisaiheen ja siitä ottaa selvää sen minkä ottaa sen ajan puitteissa ja sitten kirjoittaa mahdollisimman kansantajusen ymmärrettävän jutun. (Ryhmähaastattelu, aluelehti) 
Kuitenkin varsinkin valtakunnallisessa mediassa työskentelevät toimittajat näkivät toimittajilla olevan merkittävästi välillistä valtaa. Asioiden esiintuomisella, aihevalinnoilla, näkökulmilla, hyviä kysymyksiä esittämällä ja haastateltavien valinnalla toimittajat vaikuttavat julkisen mielipiteen muotoutumiseen. Toimittajalla on asemansa tuoma mandaatti saada, käsitellä ja analysoida tietoa, johon muilla ei ole pääsyä, ja tätä kautta vaikuttaa yhteiskunnalliseen kehitykseen. Nämä ymmärrettiin merkittäviksi vallankäytön muodoiksi, jotka tuovat mukanaan myös vastuuta. Haastateltavat toivat välillisesti esiin autonomisuuden ihannetta todeten, että ilman tällaisia vaikutusmahdollisuuksia toimittajat olisivat pelkkiä kirjureita, joiden työllä ei olisi nykyisenlaista yhteiskunnallista merkitystä.

Suomalainen toimittaja siis vaikuttaa hahmottavan itsensä puolueettomana ja riippumattomana toimijana, joka kuitenkin ottaa huomioon yleisönsä ja pyrkii kertomaan asiansa tasapuolisesti, ymmärrettävästi ja tarinallisuutta ilmaisussaan hyödyntäen. Toimittajat välttävät vaikuttamasta asioihin liian suoraan ja ottamasta kantaa poliittisesti, mutta myöntävät valtansa muuten - joskaan käsitystä omasta vallasta ja sen ulottuvuuksista ei aina kovin tietoisesti pohdita käytännön työtä tehtäessä.

\section{Eettisyyden ristiriita: Toimintaympäristön muutokset vaativat joustoa}

Eettisyys nähtiin kyselyn useissa eri osissa erittäin keskeisenä, ellei jopa tärkeimpänä ammatillisena arvona. Ryhmähaastatteluissa käydyt keskustelut kuitenkin osoittavat, ettei etiikka ole pelkkä ammatillinen itsestäänselvyys. Eettisyys on selkein esimerkki ydinarvosta, johon teknis-taloudelliset resurssipaineet näyttävät tuottavan ristiriitoja arkisessa työssä ihanteen ja käytännön välillä. Se on siksi syytä nostaa oman tarkastelun kohteeksi. Kyselytutkimuksen perusteella 98 prosenttia vastaajista oli vähintään jossain määrin yhtä mieltä siitä perusajatuksesta, että journalistien on noudatettava ammattieettisiä ohjeita - siis Journalistin ohjeita - työssään aina tilanteesta ja kontekstista riippumatta. Toimittajien aiemmin esittämät huolet eettisyyteen sitoutumisen heikkenemisestä (Jyrkiäinen 2008, 50) eivät siten ole käyneet toimittajien ajattelun tasolla toteen.

Toimittajat kuitenkin näkivät ammattietiikan käytännön soveltamisessa jonkin verran harkinnan varaa. Hieman yli kolmannes vastaajista hyväksyisi tilannekohtaisen eettisen harkinnan, mutta yli puolet oli sitä mieltä, ettei etiikka taivu tilanteen mukaan. Vielä vähemmän hyväksyttävänä nähtiin henkilökohtaiseen harkintaan perustuva eettisyys. Sen kannalla oli vain joka neljäs ja sitä vastusti $61 \%$ toimittajista. Vastauksissa oli hajontaa sikäli, että alle kymmenen vuotta uralla ollut toimittajapolvi oli valmiimpi hyväksymään eettistä tilannekohtaista harkintaa (jossain määrin tai vahvasti samaa mieltä $43 \%$ vastaajista) kuin kokenein, yli 20 vuotta työskennellyt toimittajapolvi (29\%).

Vastaavanlaisen havainnon politiikan toimittajien arvoista tehnyt Kantola yhdistää sukupolvierot journalismin arvojen notkistumiseen, nuorten toimittajien instituutio- 
kriittisyyteen sekä ulkomailta saatuihin vaikutteisiin (2011, 134-138). Ryhmähaastattelut puolsivat kyselyn tuloksia ja Kantolan havaintoa vain osin. Ne eivät tuoneet esiin varsinaisia ikäpolvieroja journalistien eettisissä käsityksissä, mutta arvojen yleistä notkistumista oli nähtävissä: toimittajan työn universaalit eettiset säännöt kyseenalaistettiin ja niiden sijaan korostettiin toimitus- ja toimittajakohtaisten määrittelyjen merkitystä. Organisaatioiden kulttuurit, kontekstit ja resurssit - eivät niinkään työvuodet tai absoluuttiset ohjeet - määrittävät siten myös journalismin professionalismia etenkin suhteessa etiikkaan:

V1: Jos mä saan vähän kyseenalaistaa tulosta niin täähän on aika suhteellista koska, mitkä on ne absoluuttiset ammattiohjeet jota noudatettas aina. Jos ensiksi ne sovitaan niin sitten voidaan kattoo että pitääks niitä noudattaa aina. Siis kun nää on niin, myös hirveen toimituskohtasia ja toimittajakohtasia. (...)

V2: Siis tässähän on kuitenkin jonkun verran hajontaa tässä, niin varmaan onkin näin koska ainakin mitä tunnen ja tiedän kollegoita muissa välineissä niin, aika paljon ihmiset ajattelee eri tavalla. Ja usein riippuen siitä missä välineessä esimerkiksi ovat töissä.

(Ryhmähaastattelu, julkisrahoitteinen media)

Toimittajat myös kertoivat tietoisesti hakeutuneensa töihin sellaiseen mediaan, jossa voivat toimia omien eettisten käsitystensä mukaisesti. Käytäntö kuvaa kansainväliselläkin kentällä havaittua tapaa sopeuttaa oma arvomaailma ja työn vaatimukset yhteen (ks. Baisnée \& Vera Zambrano 2014). Etiikan joustavuutta perusteltiin suomalaisessa kontekstissa lisäksi Journalistin ohjeilla, jonka varsin väljästi kirjoitettu säännöstö mahdollistaa "järjen käytön" ohjeita hyödynnettäessä.

Kyselyssä journalisteille esitettiin arvioitavaksi myös tiedonhankintaan ja uutistuotantoon liittyviä toimintatapoja, jotka voisivat olla eettisesti arveluttavia. Toimittajat ottivat kantaa siihen, pitävätkö he toimintatapoja "tärkeän jutun" tekoprosessissa oikeutettuina vai eivät. Vastauksista käy ilmi toimittajien vahva usko autonomian ja objektiivisuuden normeihin sekä Journalistin ohjeisiin. Sekä periaatteita että Journalistin ohjeita rikkovia toimenpiteitä ei hyväksytä lainkaan: 99 \% ei hyväksy missään olosuhteissa rahan vastaanottoa lähteiltä (JO 2014 4§), ja 98 \% ei hyväksy missään olosuhteissa lainausten manipulointia tai keksimistä (JO $20148 \S, 11 \S$ ). Toisaalta erityisesti jotkin tutkivan journalismin toimintatavat voitaisiin hyväksyä joskus. Näitä olivat organisaatioon pestautuminen (75 \% pitää aina tai joskus hyväksyttynä), uutistapahtumien rekonstruointi ja dramatisointi (72\%) ja luottamuksellisten dokumenttien käyttö ilman lupaa (81\%).

Esitetyt toimintatavat herättivät ryhmähaastatteluissa kuitenkin jopa hilpeyttä, eikä monia niistä pidetty sellaisenaan mahdollisina suomalaisen journalistin työssä: useimmiten tavallisten toimintatapojen on riitettävä, eikä esimerkiksi paikallistoimittaja voi kuvitellakaan soluttautuvansa tai käyttävänsä luottamustaan väärin. Poikkeavien menettelytapojen käyttöön oltiin valmiita julkisen palvelun arvon pohjalta lähinnä tapauksissa, joissa on oleellista saada kerrottua yleisölle jostakin tärkeästä yhteiskunnallisesta asiasta (ks. JO 2014, 9§). 
[T]otta kai on tilanteita josta sä saat sen oikeen painavan yhteiskunnallisesti merkittävän tiedon jos oot ees saadaksesi niin vain jos sä oot siellä ikään kuin yhtenä muista, koska totta kai toimittajia varten pannaan show pystyyn jos on joku. Että mun mielestä se on ihan selvä juttu ja journalistin ohjeet sen siunaa. (Ryhmähaastattelu, aikakauslehti)

Sen sijaan aktiivista eettistä pohdintaa herättivät etenkin lähteisiin, niiden käyttöön ja suojeluun liittyvät asiat. Ryhmähaastatteluissa pidettiin tärkeänä, että lähteitä lainataan tasapuolisesti ja lähteet tuodaan jutussa esiin siten, ettei se aiheuta heille henkilökohtaista kärsimystä tai haittaa. Lähteen haluttiin esiintyvän jutussa edukseen, sillä se on hyväksi myös jutulle. Lähteet eivät kuitenkaan saisi olla toimittajalle liian läheisiä, koska se voisi vaarantaa juttujen riippumattomuuden ja objektiivisuuden. Toisinaan näiden kahden pyrkimyksen yhdistäminen on vaikeaa:

Aika nopeesti tulee se raja vastaan, siis jos ajattelee että on tavannu vaikka vaan työyhteyksissä ettei oo mikään ystävä mut on vaikka useemman kerran haastatellu tai tavannu jossain tilaisuuksissa, ni kyllähän se, kyllä mä ainakin ihan voin rehellisesti sanoo että kyllä se sitten on vaikeempaa heti tehdä se, vaikka kielteinen juttu tähän henkilöön tai hänen edustamaansa tahoon liittyen. (...) Et se on semmonen mitä täytyy jokaisen toimittajan tietenkin, ylipäätään niit suhteita ja kaikkii niit haastattelutilanteit ja kaikkii miettii koko ajan. (...) Ja sit kuitenki, vaikka monilla meistä, tai mulla ainaki kuitenki tulee semmonen olo et kuitenki vähän tekis mieli miellyttää.

(Ryhmähaastattelu, julkisrahoitteinen media)

Ongelmien välttämiseksi toimittajat kertoivat olevansa tiukkoja mahdollisissa jääviysasioissa ja ilmoittavansa niistä herkästi toimituksen johdolle (vrt. JO 2014, 4§). Erityisesti aikakaus- ja paikallislehtien toimittajat kuitenkin tunnistivat tarpeen olla lähteille suopea. Aikakauslehtien autonomiaa koettelee tarve pitää yllä suhteita vakiojulkkiksiin, joiden kasvoilla lehtiä myydään ja jotka usein saavat antamistaan jutuista ja kuvauksista palkkion. Lehdillä ei ole varaa riskeerata näitä suhteita, joten lähdesuhteet voivat muotoutua toisenlaisiksi kuin muiden toimijoiden kanssa.

Paikallislehdissä taas pyritään olemaan tarkkoja siitä, ettei sorruta liikaan hymistelyyn paikallisten asioiden käsittelyssä, mutta samalla joudutaan ottamaan huomioon erityisesti mainostajien tuntoja, sillä mediamainonnan kutistuessa hyvät tulonlähteet ovat yhä harvemmassa (Nikunen 2011, 25). Ulkomaantoimittajat olivat lisäksi joutuneet pohtimaan suhdettaan lähteisiin, jotka odottavat maksua antamistaan lausunnoista. Näihin oli yleensä muodossa tai toisessa suostuttu (esimerkiksi antamalla tuliaislahjoja), jotta saataisiin ylipäänsä jotain tietoa. Esimerkkinä nostettiin esiin Romania ja maassa romaneista tehdyt jutut.

Vaikka suomalaistoimittajat sijoittivat kyselytutkimuksessa eettisyyden ammatillisuutensa ytimeen, etenkin ryhmähaastattelujen pohdinnat heijastavat lisääntynyttä joustavuutta ja jopa ristiriitoja eettisissä käsityksissä. Toimittajien suhtautumista etiikkaan selittää osaltaan muuttunut toimintaympäristö, jossa totuuden kertominen on edelleen journalistille oleellinen tehtävä mutta jossa yhä tarkemmin joudutaan pun- 
taroimaan myös totuuden kertomisesta aiheutuvia seurauksia joko tiedon kohteen, journalistin itsensä tai mediayhtiön kannalta (Koljonen 2013a, 85-89; Juntunen 2009). Myös Internet ja sosiaalinen media tuovat työhön mukanaan uusia, jatkuvasti muuttuvia elementtejä, joiden eettiseen arviointiin ei ole olemassa vakiintunutta säännöstöä (Vainikka ym. 2013).

\section{Johtopäätökset}

Olemme tässä artikkelissa käsitelleet suomalaistoimittajien ammatillista itseymmärrystä diskursiivisesta näkökulmasta ja antaneet journalisteille mahdollisuuden itsearviointiin. Toimittajat kertovat tekevänsä työtään toimintaympäristössä, jossa korostuvat teknis-taloudelliset muutokset sekä niistä johtuvat resurssivähennykset. Talouden ei välttämättä (haluta) nähdä vaikuttavan suoraviivaisesti journalismin sisältöihin, mutta ainakin käytettävissä olevien resurssien kautta sillä on suuri vaikutus siihen, mitä ja millaista journalismia toimittajien on mahdollista työnään tehdä. Teknologiset muutokset taas tarjoavat yhtäältä mahdollisuuden entistä laadukkaamman ja monipuolisemman journalismin tekemiseen, mutta toisaalta ne lisäävät talouspaineiden, kasvaneen yleisölähtöisyyden ja johtamisongelmien kanssa toimittajien huolta sisältöjen laadusta, työrauhasta ja työn autonomisuudestakin.

Paineista huolimatta analyysimme piirtää kuvan suomalaisesta toimittajakunnasta varsin yhtenäisenä ammatillisena ryhmänä, jota muutostenkin keskellä pitää koossa jaettu ymmärrys journalismin peruspilareista. Etenkin autonomisuus, objektiivisuus ja julkinen palvelu määrittelevät suomalaisten journalistien diskursiivista itseymmärrystä: näihin arvoihin halutaan sitoutua ja niitä halutaan pitää yllä. Suomalaiset toimittajat kokevat, että erilaiset ulkopuoliset tahot ja instituutiot eivät pääse vaikuttamaan heidän toimintaansa vahvasti - tai ainakin niiden vaikutuspyrkimykset pyritään ohittamaan ja toteuttamaan journalismia itsesääntelyn ohjaamana. Tämän lisäksi journalismin poliittisesti sävyttynyttä vaikuttavuutta kavahdetaan. Autonomian ihanne pitää suomalaiset journalistit enemmän tiedon välittäjinä kuin aktiivisina kansalaistoiminnan mobilisoijina, vaikka viitteitä kasvavasta yleisöyhteistyöstä onkin.

Autonomisuuden lisäksi objektiivisuus pitää edelleen pintansa ammatillisena arvona, mutta keinot sen saavuttamiseen tuntuvat olevan entistä moninaisemmat. Esimerkiksi tarinoiden kertominen ei tunnu olevan ristiriidassa objektiivisuuden ihanteen kanssa. Myös julkisen palvelun ydinarvo vaikuttaa aineistomme perusteella edelleen vahvalta, mutta yleisösuhteen lisääntynyt pohdinta näyttää laventaneen ja uudelleenmääritelleen nimenomaan tätä ihannetta kohti yleisölähtöistä ammattiidentiteettiä. Kaikkien suoraviivaisimpia tapoja kuluttajien houkutteluun tai puhutteluun kuitenkin kavahdetaan, vaikka brändiajattelua ollaankin valmiita ymmärtämään.

Ammatillisen rehellisyyden ja kehittymisen näkökulmasta toimittajien tiukka kiinnittyminen professionalismin ydinarvoihin voi toki näyttää myös ongelmalliselta. Ajoittain aineistomme antaa nimittäin kuvan, jonka mukaan toimittajat tuntuvat ajattelevan, että maailma muuttuu mutta journalismin ei tarvitse. Keskeisten arvojen 
pysyvyyttä selittää kuitenkin ainakin se, että niiden avulla toimittajat ylläpitävät uskoa työn tekemisen mielekkyyteen. Tällaisina henkilökohtaisen motivaation lähteinä arvot toimivat "sisäänpäin" ja vahvistavat asemaansa ammatillisen identiteetin rakennuspuina. Ydinarvoihin voidaan toki vedota myös perusteltaessa journalismin yhteiskunnallista asemaa ja ammattikunnan merkittävyyttä "ulospäin" yhteiskunnan muille toimijoille. Tämän vuoksi tiettyjen arvojen järkähtämättömyys on tietenkin myös osa journalistikunnan maineenrakennusta, jolle tuntuu olevan mediakentän toimijoiden moninaistumisen myötä entistä enemmän tarvetta.

Yllä summattujen kohtalaisten pysyvien arvojen lisäksi havaitsimme kuitenkin myös arvoja, jotka olivat liikkeessä ja jopa ristiriitaisten pohdintojen kohteena. Näitä olivat ajankohtaisuuden ja eettisyyden ideaalit. Ensinnäkin ajankohtaisuuden vaade tuntuu digitalisoituneessa toimintaympäristössä entisestään vahvistuneen, sillä uutisten julkaisemisen tahti on kiihtynyt ja jatkuvan päivittämisen tarve korostunut. Uusi teknologia ja taloudellinen tiukkuus ovat korostaneet vaatimusta nopeudesta ja lisänneet kiireen tuntua, jolloin toimittajat kokevat ristiriitaa nopeus- ja laatuvaatimusten välillä. Samalla tämä ristiriita tuntuu olevan hyväksytty osa toimittajaidentiteettiä. Toimittajien tulkinnoissa aikapaine käännetään ammatilliseksi hyveeksi ongelmallisuudestaan huolimatta - kiireen sietäminen on oleellinen osa nykyjournalistin ammatillisuutta ja vastaus ajankohtaisuuden korostuneeseen vaatimukseen.

Eettisyys sen sijaan aiheuttaa selvää ristiriitaa toimittajien tulkinnoissa. Sitoutuminen eettisyyden ideaan on yksi keskeisimpiä suomalaistoimittajia ammattikunnaksi yhdistäviä arvoja, mutta toimintaympäristön muutos tuo mukanaan paineita, joissa eettisyydestä joudutaan käytännön toiminnassa usein jopa tinkimään. Ihanteen ja käytännön ristiriita on tämän arvon kohdalla kaikkein suurin. Etenkin lähdesuhteisiin tuntuu kiteytyvän monia eettisiä ongelmia ja ne saavat organisaatiokohtaisia tulkintoja, jolloin ammattikunnan yhteneväisyys alkaakin murentua. Haastattelemiemme toimittajien mukaan on kuitenkin absurdia ajatella, että vaikka tekniikka muuttuu ja kiire kasvaa, journalistien sitoutumisen eettisyyteen tulisi muuttua merkittävästi. Ratkaisut ristiriitoihin haetaan muuta kautta kuin varsinaisesti löysentämällä sitoutumista tähän arvoon - usein käytännössä sietämällä turhautumista ja sovittamalla omaa tekemistä olemassa oleviin vaatimuksiin - jotta ammatillinen arvoydin säilyisi, niin oman motivaation kuin ammattikunnan yhteiskunnallisen asemankin vuoksi.

Toimittajan työhön käytännössä kohdistuvia paineita ja työtä koskevia arvoja ei siten ole tarpeen nähdä toisilleen täysin vastakkaisina voimina (vrt. Juntunen 2009, 39). Paineet vaikuttavat siten, että käytäntöä muokataan ihanteisiin sopivaksi, ja toisaalta arkiset käytännöt kehystävät suhtautumista ihanteisiin. Esimerkiksi tarve puntaroida eettisiä kysymyksiä, kuten lähdesuhteita, vahvistaa eettisyyden arvon yleistä roolia ammatillisuuden diskursiivisen rakentumisen tukipilarina, vaikka tätä pohdintaa voi tulkita myös ammatillisuuden "notkistumisena" (Kantola 2011; Koljonen 2013) tai yhtenäisyyden murentumisena. Tulkintamme mukaan eettisyys on yhä suomalaisen journalismin keskeinen diskursiivinen solmukohta, koska sen ympärillä käydään aktiivista neuvottelua. Tätä neuvottelua toimintatavoista käydään etenkin ammattikunnan sisällä, vaikka "ulospäin" eettisyys usein näyttäytyykin ongelmattomana ammattilaisena ihanteena. 


\section{Viitteet}

$1 \quad$ WJS-tutkimuksessa keskeisenä käsitteenä on journalistinen kulttuuri (ks. Hanitzsch 2007), ja hanke pyrkii kartoittamaan, kuinka yhtenevää tai eroavaa journalistinen kulttuuri on lähes 80 eri maassa. Artikkelin kirjoittajat ovat vastanneet Suomen-osatutkimuksen toteutuksesta, ja tässä eriteltävä määrällinen tutkimus seuraa läheisesti vertailevan yhteishankkeen suuntaviivoja. Ks. lisää www. worldsofjournalism.org.

2 Koska WJS-tutkimuksessa käytetty toimittajan määritelmä poikkeaa jonkin verran esimerkiksi Suomen Journalistiliiton vastaavasta, suomalaisten toimittajien määrä täytyi ensin määrittää erilaisista lähteistä (mediatalot, Journalistiliitto, aiemmat tutkimukset). Journalistiliiton journalistimääritelmä tarkemmin: www.journalistiliitto.fi/jasenpalvelut/jaseneksi/jasenrajat_ saannoissa/.

3 Oletettua suuremman kiintiön saivat Yle (64 vastaajaa: 33 radiosta, 24 TV:stä ja 7 verkosta), MTV 3 (12 - 10 TV:stä ja 2 verkosta), Helsingin Sanomat (7: 5 lehdestä ja 2 verkosta), llta-Sanomat (6: 4 lehdestä ja 2 verkosta) ja STT-Lehtikuva (6). Valinta pohjautuu lähinnä sähköisen median työpaikkojen keskittymiseen.

$4 \quad$ Palkkasuhteessa olleet vastaajat ja osa freelancereistakin hankittiin päälliköiden kautta tutkimuseettisistä syistä (haluttiin varmistaa, että toimitusten johdossa saadaan tietää tutkimuksesta ja annetaan alaisille lupa osallistua) ja käytännön syistä (kaikkien toimittajien yhteystietoja ei ole koottu Suomessa yhtenäiseen rekisteriin, joten päälliköiden kautta eteneminen oli nopein vaihtoehto, ja sen arveltiin myös parantavan vastaajien innokkuutta osallistua kyselyyn). Loput freelancerit hankittiin vastaajiksi free-toimittajien yhdistyksen aktiivien kautta sekä hyödyntämällä verkossa olevaa free-luetteloa (http://freeluettelo.fi/). Koska ei ole tietoa, miten päälliköt ovat alaisiaan vastaajiksi rekrytoineet, lopullista vastausprosenttia on mahdotonta sanoa tarkasti. Tekijöiden valistunut arvaus koko otoksen osalta on 50-55 \%: palkkasuhteisten osalta n. $70 \%$ ja freelancereiden osalta n. $30 \%$.

5 Johtavassa asemassa olevista toimittajista on yliedustus, sillä tekijöiden arvio on, että ylemmän ja keskiportaan johtoa olisi tullut olla otoksessa korkeintaan $15 \%$ vastaajakunnasta. Tämä johtuu aineistokeruutavasta: pienemmissä medioissa monet päälliköt vastasivat yhteydenoton yhteydessä kyselyyn heti itse ja isommissa delegoivat työn jollekin toiselle johtavassa asemassa olevalle rivitoimittajia säästääkseen. Virheen ei kuitenkaan uskottu vaikuttavan merkittävästi tuloksiin, sillä varsinkin pienissä medioissa toimitusten matalan hierarkian on arveltu yhdenmukaistavan journalistien arvoja (vrt. Lauk, Harro-Loit \& Väliverronen 2014, 87).

6 Kyselylomakkeen pohjana toimi WJS-tutkimuksessa käytettävä malli, joka käännettiin suomeksi. Lomake on nähtävillä kokonaisuudessaan verkossa: www.uta.fi/cmt/tutkimus/comet/tutkimus/ Worlds_of_Journalism_Study.html. Suomalaisella tutkimusryhmällä ei ollut mahdollisuuksia tehdä muutoksia lomakkeeseen vertailtavuuden vuoksi. Haastattelijoina toimi neljä tutkimusapulaista.

7 Vastauksia ryhmiteltiin ja tarkasteltiin vastaajan iän, työvuosien määrän, työsuhteen muodon ja keston, aseman toimituksessa, koulutustaustan, sukupuolen ja työnantajamedian tavoittavuuden mukaan. Eriteltyjä jakaumia käsitellään tarkemmin hankkeen raportissa (Pöyhtäri, Väliverronen \& Ahva 2014).

8 Kyselyyn vastanneet toimittajat esittivät myös paljon kritiikkiä kyselylomakkeesta ja kysymysten muotoilusta (ks. Pöyhtäri, Väliverronen \& Ahva 2014).

9 Ryhmähaastatelluista osa on saattanut osallistua myös kyselytutkimusosioon, mutta asiaa ei toimittajilta tiedusteltu, eikä se ollut kriteeri ryhmähaastatteluun osallistumiselle.

1091 \% arvioi, että tällä on vain vähän tai ei lainkaan vaikutusta työhön. Useat kyselyyn vastanneet myös kritisoivat kysymyksenasettelua. Vastaajien mukaan oli hankala erotella, puhutaanko työstä yleisesti ottaen vai omasta työtä.

1176 \% arvioi, että medialaeilla ja säännöksillä on hyvin tai erittäin suuri vaikutus. Journalismietiikan kohdalla $89 \%$ vastaajista teki saman arvion.

12 Kysyttyjä tekijöitä olivat journalistikoulutus, eettiset normit, kilpailu, mainonta ja mainostajat, tulospaineet, suhdetoiminta ja PR, yleisötutkimus, käyttäjien tuottama sisältö kuten blogit, sosiaalinen media kuten Facebook ja Twitter, yleisön osallistuminen uutistuotantoon, yleisöpalaute ja sensaatiohakuisuus.

13 Pyöristysten ja taulukosta poistettujen ei osaa sanoa -vastausten vuoksi kenttien summa ei ole aina 100.

14 Vastausvaihtoehtoina olivat "ei lainkaan tärkeä", "ei kovin tärkeä", "jonkin verran tärkeä", "hyvin tärkeä" ja "erittäin tärkeä". Lisäksi saattoi vastata "en tiedä" tai "en halua vastata". 
15 Suluissa esitetyt lukemat kertovat artikkelin tässä osiossa, kuinka suuri osa vastaajista piti mainittua roolia hyvin tai erittäin tärkeänä.

16 Termi "notkea moderni" on puolalaisen sosiologin Zygmunt Baumanin (2000) kehittämä. Sillä viitataan mm. yhteiskuntien yksilöllistymiseen, ihmisten vähenevään auktoriteettiuskoon ja elämänkulun aiempaa suurempaan arvaamattomuuteen.

\section{Kirjallisuus}

Ahva, Laura (2010). Making News with Citizens: Public Journalism and Professional Reflexivity in Finnish Newspapers. Tampere: Tampere University Press.

Ahva, Laura \& Pantti, Mervi (2015). Amatöörikuvien läheisyys kriisiuutisissa toimittajien ja yleisön tulkitsemina. Media Q viestintä 38:1, 23-39.

Aldridge, Meryl \& Evetts, Julia (2003). Rethinking the concept of professionalism: The case of journalism. British Journal of Sociology 54:4, 547-564.

Baisnée, Olivier \& Vera Zambrano, Sandra (2014). Realms of influence on media accountability. Teoksessa: Fengler, Susanne; Eberwein, Tobias; Mazzoleni, Gianpietro; Porlezza, Colin \& RussMohl, Stephan (toim.). Journalists and Media Accountability: An International Study of News People in the Digital Age. Mass Communication and Journalism, Volume 12. New York: Peter Lang, 181192.

Bauman, Zygmunt (2000). Liquid Modernity. Cambridge: Polity Press.

Carey, James W. (2007). A short history of journalism for journalists: A proposal and essay. Press/Politics 12:1, 3-16.

Carpentier, Nico (2005). Identity, contingency and rigidity. The (counter-)hegemonic constructions of the identity of the media professional. Journalism 6:2, 199-219.

Conboy, Martin (2004). Journalism: A Critical History. London: Sage.

Costera Meijer, Irene (2013). Valuable journalism: A search for quality from the vantage point of the user. Journalism 14:6, 754-770.

Davies, Nick (2008). Flat Earth News: An Award-winning Reporter Exposes Falsehood, Distortion and Propaganda in the Global Media. London: Chatto \& Windus.

Deuze, Mark (2005). What is journalism? Professional identity and ideology of journalists reconsidered. Journalism. Theory, Practice Q Criticism 6:4, 442-464.

Edmonds, Rick; Guskin, Emily; Mitchell, Amy \& Jurkowitz, Mark (2013). Newspapers: Stabilizing, but still threatened. The Pew Research Center's Project for Excellence in Journalism: The State of the News Media 2013 - An Annual Report on American Journalism. Saatavilla: http://stateofthemedia. org/2013/newspapers-stabilizing-but-still-threatened/ (luettu 9.9.2014).

Hallin, Daniel (1992). The passing of the "high modernism" of American journalism. Journal of Communication 42:3, 14-25.

Hanitzsch, Thomas (2007). Deconstructing journalism culture: Towards a universal theory. Communication Theory 17:4, 367-385.

Hanitzsch, Thomas (2011). Populist disseminators, detached watchdogs, critical change agents and opportunist facilitators: Professional milieus, the journalistic field and autonomy in 18 Countries. International Communication Gazette, 73:6, 477-494.

Heikkilä, Heikki (2001). Ohut ja vankka journalismi. Kansalaisuus suomalaisen uutisjournalismin käytännöissä 1990-luvulla. Tampere: Tampereen yliopistopaino.

Heikkilä, Heikki; Ahva, Laura; Siljamäki, Jaana \& Valtonen, Sanna (2012). Kelluva kiinnostavuus: Journalismin merkitys ihmisten sosiaalisissa verkostoissa. Tampere: Vastapaino.

Heinonen, Ari (1995). Vahtikoiran omatunto. Journalismin itsesääntely ja toimittajat. Tampere: Tampereen yliopisto.

Heinonen, Ari (2008). Yleisön sanansijat sanomalehdissä. Tampereen yliopisto: Tiedotusopin laitos, Julkaisuja A108.

Heinonen, Ari \& Luostarinen, Heikki (2008). Reconsidering “journalism” for journalism research. Teoksessa: Löffelholz, Martin \& Weaver, David (toim.). Global Journalism Research: Theories, Methods, Findings, Future. Blackwell: Malden, 227-239.

Helander, Voitto (1993). Professiot ja julkisvalta. Helsinki: Valtionhallinnon kehittämiskeskus. 
Herkman, Juha (2009). Journalismi markkinoilla. Konserni- ja mediajournalismia. Teoksessa: Väliverronen, Esa (toim.). Journalismi murroksessa. Helsinki: Gaudeamus, 32-49.

Holmes, Tim \& Nice, Liz (2012). Magazine Journalism. Thousand Oaks: Sage Publications.

Honkonen, Juha \& Lankinen, Jussi (2012). Huonoja uutisia - näin mediatalot pilaavat journalismin. Helsinki: Into Kustannus.

Hujanen, Jaana (2009). Kiinnostavaa vai tärkeää? Ihmisläheisen journalismin kaksi polkua. Teoksessa: Väliverronen, Esa (toim.). Journalismi murroksessa. Helsinki: Gaudeamus, 112-128.

JO (2014). Journalistin ohjeet ja liite. Saatavilla: http://www.jsn.fi/journalistin_ohjeet/ (luettu 19.5.2015).

Juntunen, Laura (2009). Journalistinen etiikka kriisissä - kiireen ja kilpailun haasteet toimittajien ammatilliselle itsekurille. Media Q Viestintä 32:2, 31-47.

Juntunen, Laura (2010). Explaining the need for speed: Speed and competition as challenges for journalism ethics. Teoksessa: Cushion, Stephen \& Lewis, Justin (toim.). The Rise of 24-hour News Television: Global Perspectives. Oxford: Peter Lang, 167-181.

Juntunen, Laura (2011). Leikkaa-liimaa-journalismia? Tutkimus uutismedian lähdekäytännöistä. Viestinnän tutkimusraportteja 4/2011. Helsinki: Helsingin yliopisto, sosiaalitieteiden laitos, viestinnän tutkimuskeskus CRC. Saatavilla: http://www.helsinki.fi/crc/Julkaisut/leikkaaliimaa_raportti.pdf (luettu 30.8.2014).

Jyrkiäinen, Jyrki (2008). Journalistit muuttuvassa mediassa. Tampereen yliopisto: Tiedotusopin laitos, Journalismin tutkimusyksikkö, Julkaisuja sarja B50.

Kantola, Anu (2011). Notkean journalismin nousu. Teoksessa: Kantola, Anu (toim.). Hetken hallitsijat. Julkinen elämä notkeassa yhteiskunnassa. Helsinki: Gaudeamus, 115-141.

Koljonen, Kari (2013a). Kriisi journalismissa. Kansakunnan katastrofit ja muuttuva professio. Tampere: Tampere University Press, Acta Universitas Tamperensis 1842.

Koljonen, Kari (2013b). Seuraa johtajaa! Väliportaan päällikkötoimittajien muuttuvat roolit. Tampere: Tampere University Press.

Koljonen, Kari (2014). Tyytyväiset uudistajat ja tyytymättömät perinnetietoiset - Vapauden kokemukset toimitusorganisaatioissa. Teoksessa: Luostarinen, Heikki \& Raittila, Pentti (toim.). Journalistin vapaus. Tampere: Vastapaino, 74-96.

Kunelius, Risto \& Ruusunoksa, Laura (2008). Mapping professional imagination: On the potential of professional culture in the newspapers of the future. Journalism Studies 9:5, 662-678.

Lauk, Epp, Harro-Loit, Halliki \& Väliverronen, Jari (2014). Media accountability through the eyes of journalists: Feedback, responsiveness, interaction. Teoksessa: Fengler, Susanne; Eberwein, Tobias; Mazzoleni, Gianpietro; Porlezza, Colin \& Russ-Mohl, Stephan (toim.). Journalists and Media Accountability: An International Study of News People in the Digital Age. Mass Communication and Journalism, Volume 12. New York: Peter Lang, 83-98.

Lehto, Keijo (2006). Aatteista arkeen: Suomalaisen seitsenpäiväisten sanomalehtien linjapapereiden synty ja muutos 1971-2005. Jyväskylä: Jyväskylän yliopisto.

Lehtonen, Pauliina (2013). Itsensä markkinoijat: Nuorten journalistien urapolut ja yksilöllistyvä työelämä. Tampere: Tampere University Press.

Lewis, Seth C. (2012). The tension between professional control and open participation: Journalism and its boundaries. Information, Communication Q Society 15:6, 836-866.

Löfgren-Nilsson, Monica (1999). På Bladet, Kuriren Q Allehanda: Om ideal och organiseringsprinciper i den redaktionella vardagen. Göteborgs Universitet: Institutionen för journalistik och masskommunikation.

Machill, Marcel; Köhler, Sebastian \& Waldhauser, Markus (2007). The use of narrative structures in television news: An experiment in innovative forms of journalistic presentation. European Journal of Communication 22:2, 185-205.

McDevitt, Michael (2003). In defense of autonomy: A critique of the public journalism critique. Journal of Communication 53:1, 155-164.

Mäntylä, Jorma (2008). Journalistin etiikka. Helsinki: Gaudeamus.

Nikunen, Kaarina (2011). Enemmän vähemmällä. Laman ja teknologisen murroksen vaikutukset suomalaisissa toimituksissa 2009-2010. Tampere: Tampereen yliopisto, Journalismin tutkimusyksikkö (tutkimusraportti).

Nordenstreng, Kaarle (1998). Professional ethics: Between fortress journalism and cosmopolitan democracy. Teoksessa: Kees Brants, Joke Hermes and Liesbet van Zoonen (toim.). The Media in Question, London: Sage, 124-34. 
Pietilä, Antti-Pekka (2007). Uutisista viihdettä, viihteestä uutisia: median muodonmuutos. Helsinki: Art House.

Pietilä, Kauko (2012). Journalismi ammattina: Journalistiprofession teoria. Helsinki: Gaudeamus.

Pöyhtäri, Reeta; Väliverronen, Jari \& Ahva, Laura (2014). Mistä on suomalainen toimittaja tehty? Worlds of Journalism -surveyn tuloksia Suomesta. Tampub, Verkkoraportti. Saatavilla: http://tampub.uta.fi/ handle/10024/95342 (luettu 7.8.2014).

Reunanen, Esa (2014). Toimittajan poliittinen identiteetti - Aktiivinen aatteenkannattaja, passiivinen puhelinpylväs vai jotain ihan muuta? Teoksessa: Luostarinen, Heikki \& Raittila, Pentti (toim.). Journalistin vapaus. Tampere: Vastapaino, 46-73.

Reunanen, Esa \& Koljonen, Kari (2014). Toimittajien sanansijat. Tampere: Tampere University Press.

SJL (2014). Jäsenmäärän kehitys: SJL:n jäsenmäärän ja sukupuolijakauman kehitys. Saatavilla: http://www. journalistiliitto.fi/liitto/alasivu/jasentilastoja/jasenmaaran-kehitys/ (luettu 19.5.2015).

Tuchman, Gaye (1973). Making news by doing work: Routinizing the unexpected. American Journal of Sociology, 79: 1, 110-131.

Töyry, Maija (2009). Lukijalähtöisyys aikakauslehtijournalismissa. Teoksessa: Väliverronen, Esa (toim.). Journalismi murroksessa. Helsinki: Gaudeamus, 129-149.

Vainikka, Eliisa; Noppari, Elina; Heinonen, Ari \& Huhtamäki, Jukka (2013). Twiiteryhmiä ja uutispäivittelyä - toimittajana sosiaalisessa mediassa. Tampere: Tampereen yliopisto. Journalismin, viestinnän ja median tutkimuskeskus COMET, tutkimusraportti.

Väliverronen, Esa (2009). Journalismi kriisissä? Teoksessa: Väliverronen, Esa (toim.). Journalismi murroksessa. Helsinki: Gaudeamus, 13-31.

Waisbord, Silvio (2013). Re-Inventing Professionalism: Journalism and News in Global Perspective. Cambridge: Polity. 